\title{
Pengaruh Variasi Tegangan Tabung Sinar-X terhadap Signal to Noise Ratio (SNR) dengan Penerapan Anode Heel Effect menggunakan Stepwedge
}

\section{Effect of X-ray Tube Voltage Variation on Signal to Noise Ratio (SNR) by Application of Anode Heel Effect using Stepwedge}

\author{
Luh Gede Puja Satwika ${ }^{{ }^{*}}$, Ni Nyoman Ratini ${ }^{2}$, Maghfirotul Iffah ${ }^{3}$ \\ ${ }^{1,2}$ Program Studi Fisika, Fakultas Matematika dan Ilmu Pengetahuan Alam, Universitas Udayana, \\ Kampus Bukit Jimbaran, Badung, Bali, Indonesia 80361 \\ ${ }^{3}$ Akademi Teknik Radiodiagnostik dan Radioterapi (ATRO) Bali, Jalan Tukad Batanghari VII No. 21, \\ Dauh Puti Klod, Denpasar Barat, Denpasar, Bali, Indonesia, 80234 \\ Email:pujasatwika@student.unud.ac.id*; nymratiniu@unud.ac.id; maghfirotul.iffah@gmail.com
}

\begin{abstract}
Abstrak - Telah dilakukan penelitian untuk menentukan pengaruh variasi tegangan tabung sinar-X $(k V)$ terhadap nilai Signal to Noise Ratio (SNR) dengan metode penerapan Anode Heel Effect menggunakan stepwedge dengan penambahan ketebalan 1,5 mm setiap step. Stepwedge yang digunakan adalah 1,5-31,5 mm. Variasi tegangan tabung sinar-X yang digunakan yaitu 40, 50, 60, 70, 80, dan 90 $k V$. Analisis pengaruh variasi tegangan tabung sinar-X terhadap nilai SNR ditentukan menggunakan IMB SPSS Statistics 26 dengan uji regresi sederhana. Hasil uji tersebut menunjukkan bahwa variasi tegangan tabung sinar-X mempengaruhi nilai SNR, dimana semakin besar variasi tegangan tabung sinar-X maka nilai SNR semakin kecil. Nilai SNR optimal yaitu 72,685 diperoleh pada tegangan tabung $40 \mathrm{kV}$ dan tebal stepwedge 27,0 $\mathrm{mm}$.
\end{abstract}

Kata kunci: Anode Heel Effect, Signal to Noise Ratio, stepwedge, tegangan tabung sinar-X, Computed Radiography

\begin{abstract}
It has been conducted research to determine the effect of X-ray tube voltage variation $(k V)$ on Signal to Noise Ratio (SNR) values by applying the Anode Heel Effect using stepwedge with the addition of $1.5 \mathrm{~mm}$ thickness each step. The stepwedge used was 1.5-31.5 mm. The X-ray tube voltage variations used were 40, 50,60,70,80, and $90 \mathrm{kV}$. Analysis of the effect of X-ray tube voltage variation on SNR values is determined using IMB SPSS Statistics 26 with a simple regression test. The test results showed that variations in X-ray tube voltage affect SNR values, where the greater the variation in X-ray tube voltage then the SNR value would get smaller. The optimal SNR value of 72.685 was obtained at a tube tension of $40 \mathrm{kV}$ and a stepwedge thickness of $27.0 \mathrm{~mm}$.
\end{abstract}

Key words: Anode Heel Effect, Signal to Noise Ratio, stepwedge, X-ray tube voltage, Computed Radiography

\section{Pendahuluan}

Radiasi sinar-X telah banyak diaplikasikan dalam berbagai bidang. Salah satunya adalah bidang medik yang memanfaatkan sinar-X dalam teknologi pencitraan [1]. Tujuannya adalah untuk menghasilkan gambaran atau citra organ tubuh sehingga mempermudah dalam mendiagnosis suatu penyakit. Citra digital yang dihasilkan harus optimal dan dapat memberikan informasi yang akurat, karena itu diperlukan teknik pencitraan yang tepat. Aspek pendukung yang digunakan adalah posisi objek, faktor eksposi, dan karakteristik tabung sinar- $X$ yang digunakan.

Salah satu karakteristik tabung sinar-X yang digunakan adalah kemiringan anoda yang dirancang untuk mengarahkan berkas sinar-X ke objek. Anoda terdapat di dalam tabung sinar-X dan merupakan fokus target elektron yang dipancarkan dari katoda. Namun, kemiringan anoda akan menyebabkan penyebaran intensitas sinar- $X$ yang tidak merata dan berpengaruh pada kualitas radiograf yang dihasilkan meskipun objek mempunyai ketebalan yang sama, hal ini disebut dengan Anode Heel Effect. Untuk itu, posisi objek yang akan diberikan sinar-X sangat penting agar mendapatkan intensitas sinar- $X$ yang 
merata [2]. Pada saat penyinaran, bagian objek yang paling tebal diletakkan pada arah katoda sedangkan bagian yang paling tipis diletakkan pada arah anoda.

Selain kemiringan dari anoda, faktor eksposi juga mempengaruhi proses pembentukan citra. Faktor eksposi yang dimaksud adalah tegangan tabung sinar-X (kV). Pesawat sinar-X dapat menghasilkan energi yang berbeda-beda berdasarkan tegangannya sehingga dapat menghasilkan daya tembus yang berbeda. Semakin besar tegangan tabung sinar- $X$ yang digunakan maka semakin besar pula daya tembus yang didapatkan [3]. Hal ini berkaitan kenaikan intensitas sinar-X yang menunjukkan jumlah energi foton yang keluar dari tabung. Adanya variasi dari tegangan tabung dapat mempengaruhi intensitas yang dihasilkan [4].

Pada proses penyinaran menggunakan sinar-X untuk menghasilkan citra digital harus memperhatikan tegangan tabung sinar-X yang digunakan, hal ini sangat penting untuk dapat menghasilkan citra digital yang optimal. Jika tegangan tabung sinar-X terlalu tinggi atau terlalu rendah maka citra yang dihasilkan tidak dapat menunjukkan bagian organ tubuh dengan baik. Untuk menggambarkan organ tubuh diperlukan citra digital dengan densitas yang sesuai. Densitas merupakan tingkat kehitaman dari citra. Densitas pada citra digital ditunjukkan dengan nilai SNR (Signal to Noise Ratio).

Adanya digitalisasi citra menggunakan Computed Radiography (CR) menyebabkan kualitas citra dapat diukur melalui nilai SNR. SNR menggambarkan tingkat perbedaan antara sinyal yang diukur dengan noise yang juga masuk dalam hasil pengukuran. Semakin besar nilai SNR, maka sinyal dan noise semakin mudah dibedakan [5]. Penggunaan SNR ini sangat penting karena akan mempengaruhi dalam proses mendiagnosis suatu penyakit dari citra yang dihasilkan.

Berdasarkan latar belakang tersebut, kemudian dilakukan penelitian untuk mengetahui bagaimana pengaruh variasi tegangan tabung sinar-X $(\mathrm{kV})$ terhadap nilai Signal to Noise Ratio (SNR) dengan metode penerapan Anode Heel Effect menggunakan objek berupa stepwedge.

\section{Landasan Teori}

\subsection{Pesawat sinar-X}

Pesawat sinar-X atau pesawat Rontgen adalah suatu alat yang digunakan untuk melakukan diagnosa medis dengan menggunakan sinar-X. Sinar-X merupakan gelombang elekromagnetik dengan frekuensi tinggi yaitu 3-30 MHz. Pesawat sinar-X dilengkapi dengan sebuah sumber tegangan tinggi 20-200 kV yang diperlukan untuk menghasilkan sinar-X [6]. Sinar-X yang dipancarkan dari tabung diarahkan pada bagian tubuh yang akan didiagnosa. Berkas sinar-X tersebut akan menembus bagian tubuh dan akan ditangkap oleh film, sehingga akan terbentuk citra dari bagian tubuh yang disinari. Sebelum pengoperasian pesawat sinar-X perlu dilakukan pengaturan parameter untuk mendapatkan sinar- $X$ yang dikehendaki. Parameter-parameter tersebut adalah tegangan tabung sinar-X $(\mathrm{kV})$, arus tabung $(\mathrm{mA})$ dan waktu paparan (s) [7].

Salah satu bagian dari pesawat sinar- $X$ adalah tabung sinar-X. Tabung sinar- $X$ adalah ruang hampa yang terbuat dari kaca tahan panas yang merupakan tempat sinar-X diproduksi. Tabung sinar-X memiliki bagian utama yaitu katoda, anoda, fokus efektif, pelindung tabung, rumah tabung, dan kolimator. Katoda adalah tempat elektron-elektron dihasilkan, terdiri dari filamen yang dipanaskan oleh arus listrik dan mengeluarkan elektron. Untuk mencapai target, elektron dipercepat dengan memberikan beda potensial yang tinggi antara anoda dan katoda. Anoda merupakan sasaran dari elektron-elektron yang dipercepat [8]. Fokus efektif didefinisikan sebagai refleksi dari daerah target tempat tumbukan dengan elektron proyektil dimana dipengaruhi oleh besarnya ukuran sudut antara target dengan sumbu bidang elektron proyektil. Pelindung tabung (tube envelope) pada umumnya terbuat dari dinding kaca yang sangat kuat dan dapat memberikan isolasi yang baik antara katoda dan anoda, serta terdapat jendela sebagai tempat lewatnya sinar- $\mathrm{X}$ menuju objek pemeriksaan. Rumah tabung (tube housing) dilapisi timah hitam $(\mathrm{Pb})$ untuk menahan berkas sinar-X yang tidak searah dengan jendela tabung. Kolimator adalah alat pembatas radiasi yang digunakan pada radiografi, terdiri dari dua set penutup (shutter) timbal yang saling berhadapan dan bergerak dengan arah berlawanan. Alat ini dilengkapi dengan pembatas luas lapangan penyinaran yang dapat diatur dan dijadikan acuan untuk menentukan titik tengah (central point) sinar-X yang keluar dari bidang target. Luas lapang sinar-X pada kolimator dapat ditentukan dengan mengatur shutter yang dapat digerakkan dari luar melalu tombol yang ada pada tabung sinar-X. Luas lapang sinar$\mathrm{X}$ yang dihasilkan dapat berbentuk bujur sangkar atau persegi panjang [7]. 


\subsection{Anode Heel Effect}

Anode Heel Effect didefenisikan sebagai bentuk penyebaran intensitas sinar-X yang tidak merata dari sisi anoda ke sisi katoda yang disebabkan oleh kemiringan permukaan anoda. Hal ini menyebabkan intensitas sinar-X yang menuju ke anoda lebih sedikit dibandingkan dengan intensitas sinar-X yang menuju ke katoda. Kemiringan anoda biasanya berkisar antara $7^{\circ}$ sampai $20^{\circ}$. Semakin besar sudut anoda akan mengakibatkan semakin besarnya luas lapangan dan fokus efektif yang dihasilkan. Dengan adanya kemiringan dari anoda akan menghasilkan perbedaan intensitas radiasi sepanjang garis pusat yang disebut Anode Heel Effect [2].

\subsection{Tegangan tabung sinar-X $(\mathrm{kV})$}

Tegangan tabung sinar-X merupakan beda potensial antara katoda dan anoda yang diperlukan untuk memindahkan elektron dari filamen pada katoda ke permukaan target (anoda). $\mathrm{kV}$ yang diatur oleh radiografer menentukan kecepatan elektron saat bergerak dari katoda ke anoda. Kecepatan elektron yang bergerak akan meningkat ketika $\mathrm{kV}$ yang diterapkan di tabung sinar-X meningkat. Semakin cepat pergerakan elektron maka semakin besar energi sinar-x yang dihasilkan. Semakin besar energi sinar-X, maka semakin besar daya tembus yang dapat melewati jaringan. Sehingga kV akan mempengaruhi kualitas sinar-X yang dihasilkan [9].

Variasi tegangan tabung sinar-X akan mempengaruhi hasil citra. Jika $\mathrm{kV}$ ditingkatkan, maka densitas dari citra akan meningkat sedangkan contrastnya akan menurun. Namun jika kV diturunkan maka densitas dari citra juga akan turun sedangkan contrastnya akan meningkat. Densitas merupakan tingkat kehitaman atau kepadatan dari citra yang dihasilkan, sedangkan contrast menggambarkan variasi tingkat kecerahan dan densitas pada citra digital. Karena hal itulah sangat penting untuk menentukan kV yang digunakan pada suatu penyinaran sehingga menghasilkan citra yang sesuai [4].

\subsection{Signal to Noise Ratio}

Salah satu parameter kualitas citra digital pada Computed Radiography (CR) adalah Signal to Noise Ratio. Parameter ini menggambarkan tingkat perbedaan antara sinyal yang diukur dengan noise yang juga masuk dalam hasil pengukuran. Semakin besar nilai SNR, maka sinyal dan noise semakin mudah dibedakan. Nilai SNR dapat dihitung dengan menggunakan persamaan (1) [5] serta letak noise dan sinyal pada citra ditunjukkan pada Gambar 1.

$$
S N R=\frac{I_{S}}{\sigma_{b}}
$$

$I_{s}$ adalah nilai rata-rata sinyal yang diterima oleh imaging plate dan $\sigma_{b}$ adalah nilai simpangan baku dari daerah noise (background).

SNR adalah metode untuk menggambarkan kekuatan paparan radiasi yang dibandingkan dengan jumlah noise yang terlihat dalam citra digital. Kekuatan atau jumlah paparan radiasi yang ditangkap oleh Image Receptor (IR) untuk membuat citra disebut dengan sinyal. Meningkatkan SNR akan meningkatkan kualitas citra digital. Meningkatkan SNR berarti kekuatan sinyal lebih tinggi dibandingkan dengan jumlah noise. Menurunnya SNR berarti ada peningkatan noise dibandingkan dengan kekuatan sinyal. Noise dapat terjadi ketika paparan sinar-X yang ditangkap oleh IR terlalu sedikit. Selain itu, noise pada perangkat elektronik yang menangkap dan memproses sinyal serta menampilkan citra digital juga dapat mempengaruhi hasil citra. SNR dalam citra digital dapat dihubungkan dengan densitas. Densitas merupakan tingkat kehitaman atau kepadatan dari citra yang dihasilkan. Semakin tinggi densitasnya maka nilai nilai rata-rata sinyal akan semakin kecil sehingga menyebabkan semakin kecil juga nilai SNRnya [4].

\subsection{Stepwedge}

Stepwedge merupakan salah satu jenis sensitometri atau metode mengukur karakteristik respon film terhadap radiasi. Stepwedge adalah suatu rangkaian panambahan ketebalan dengan bahan yang memiliki tingkat penyerapan yang sama. Alat ini biasanya terbuat dari bahan alumunium yang dibuat step bertingkat ketebalannya, yaitu dari tipis sampai tebal dengan penambahan ketebalan 1,5 mm setiap step. Pada stepwedge dengan 21 step memiliki ketebalan minimum dan maksimum yaitu 1,5 mm dan 31,5 $\mathrm{mm}$. Bagian tertentu pada stepwedge dilapisi timbal agar terbentuk tingkat irisan ketebalan pada citra digital. Stepwedge digunakan untuk menghasilkan tingkat irisan pada film radiografi melalui eksposi 
sinar-X, alat ini sangat baik untuk memonitor peralatan sinar-X dan dikombinasikan dengan Imaging Plate [11].
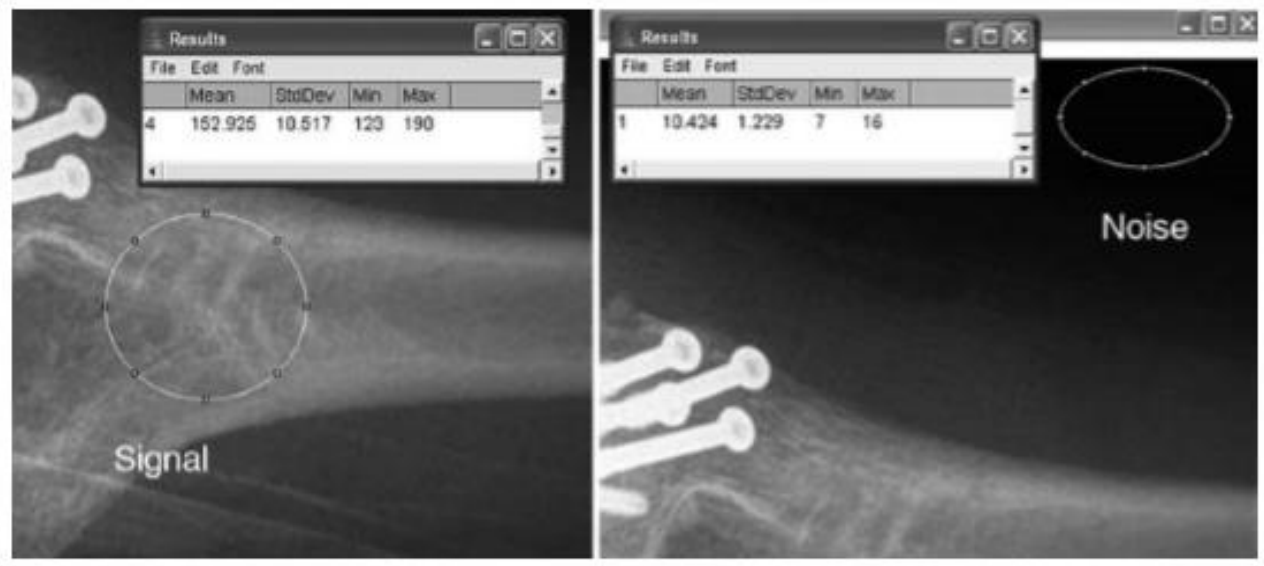

Gambar 1. Letak noise dan sinyal pada citra [10].

\section{Metode Penelitian}

Penelitian dilaksanakan di Akademi Teknik Radiodiagnostik dan Radioterapi (ATRO) Bali. Alat-alat yang digunakan pada penelitian ini adalah pesawat sinar-X, tabung sinar-X, Computed Radiography (CR), kaset CR, scanner CR, stepwedge 21 step dengan penambahan ketebalan 1,5 mm setiap step, dan software program RadiAnt DICOM VIEWER 2020.1 (64 bit). Alat-alat tersebut ditunjukkan pada Gambar 2.

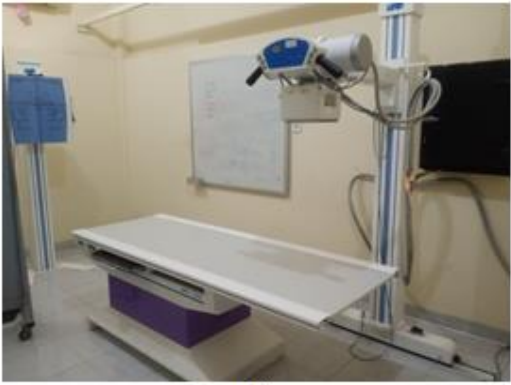

a)

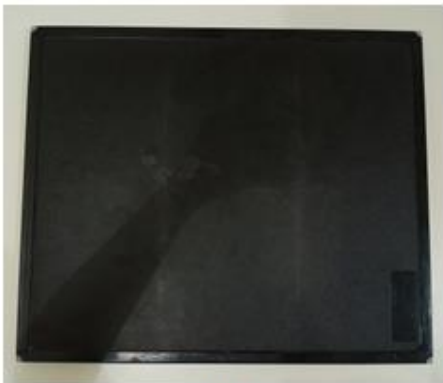

d)

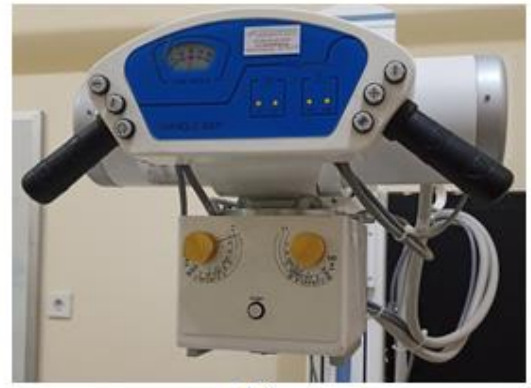

b)

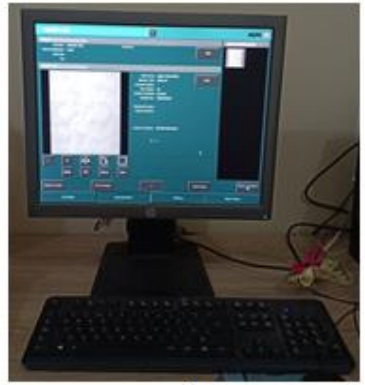

c)

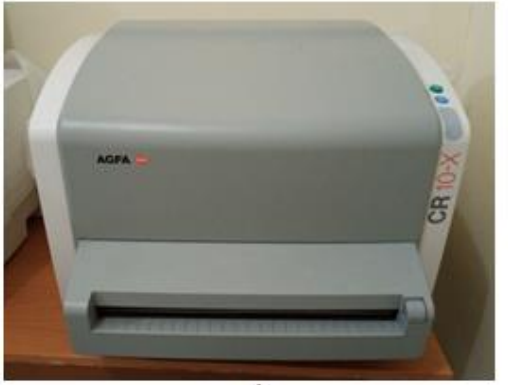

e)

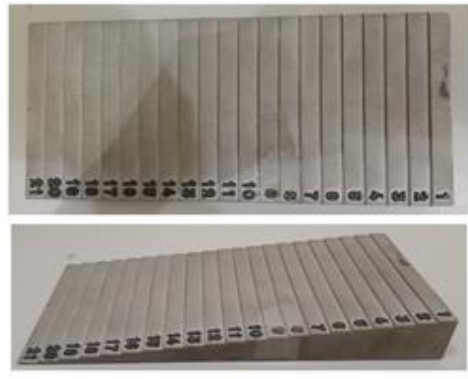

f)

Gambar 2. (a) Pesawat sinar-X, (b) tabung sinar-X, (c) Computed Radiography, (d) kaset CR, (e) scanner CR, dan (f) stepwedge.

Sebelum melakukan penelitian, pesawat sinar-X dihidupkan dan dilakukan prosedur warm up dengan kolimator menghadap ke meja pemeriksaan. Kaset CR kemudian diletakkan di atas meja pemeriksaan. Selanjutnya stepwedge diposisikan di tengah kaset CR, dimana bagian yang paling tebal diletakkan pada arah katoda, dan bagian yang paling tipis diletakkan pada arah anoda. Lalu kolimator diatur dengan FFD sebesar $100 \mathrm{~cm}$. Lampu kolimator dihidupkan serta disesuaikan dengan luas stepwedge dan central ray atau arah sinar tegak lurus dipertengahan stepwedge. Faktor eksposi diatur dengan tegangan tabung sinar- 
$\mathrm{X}(\mathrm{kV})$ sebesar $40 \mathrm{kV}$, arus sebesar $100 \mathrm{~mA}$ dan waktu sebesar 0,05 detik. Selanjutnya dilakukan eksposi atau penyinaran. Kaset CR yang telah di eksposi dilakukan proses image reader oleh scanner sehingga hasil citra akan muncul pada layar monitor CR. Langkah ini dilakukan kembali dengan variasi tegangan lainnya yaitu 50,60, 70, 80, dan $90 \mathrm{kV}$. Hasil citra kemudian dilakukan pembacaan nilai $\mathrm{I}_{\mathrm{s}}$, dan $\sigma_{\mathrm{b}}$ menggunakan software program RadiAnt DICOM VIEWER 2020.1 sesuai dengan ROI (Region of Interest) yang telah ditentukan pada masing-masing ketebalan stepwedge. Luas ROI yang digunakan sebesar $0,241 \mathrm{~cm}^{2}$. Pembacaan nilai pada ROI dilakukan dengan 3 kali pengulangan, ditunjukkan pada Gambar 3. Dari nilai $I_{s}$ dan $\sigma_{b}$ kemudian dilakukan perhitungan untuk menentukan nilai SNR. Selanjutnya dilakukan analisis data pengaruh variasi tegangan sinar-X terhadap perubahan nilai SNR.

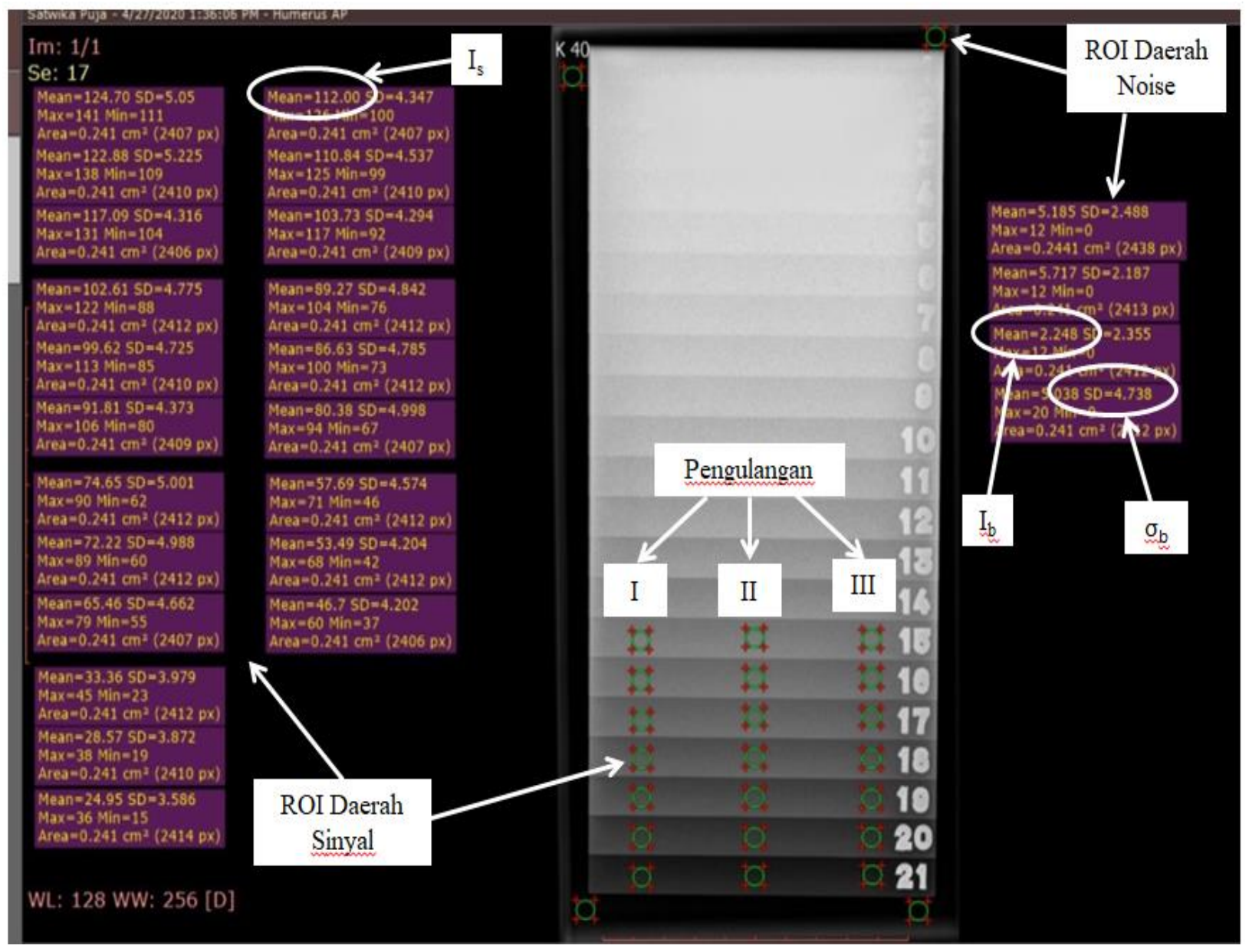

Gambar 3. Proses pembacaan nilai $I_{s}, I_{b}$, dan $\sigma_{b}$.

Analisis pengaruh variasi tegangan tabung sinar-X terhadap nilai SNR menggunakan IMB SPSS Statistics 26 dengan uji regresi sederhana. Sedangkan analisis untuk menentukan tegangan tabung sinar$\mathrm{X}$ yang menghasilkan citra paling optimal dilakukan berdasarkan grafik antara variasi ketebalan stepwedge dengan nilai SNR pada setiap tegangan tabung sinar-X. Dari grafik tersebut kemudian ditentukan nilai SNR yang optimal.

\section{Hasil Dan Pembahasan}

Hasil nilai SNR pada masing-masing variasi tegangan tabung sinar-X yang ditunjukkan pada Tabel 1. Dari hasil tersebut kemudian dilakukan uji regresi sederhana. Hasil uji regresi sederhana ditunjukkan pada Gambar 4.

Pada Gambar 4 menunjukkan nilai koefisien korelasi (R) sebesar 0,973 dan koefisien determinasi (R2) sebesar 0,946, artinya variasi tegangan tabung sinar-X akan mempengaruhi nilai SNR sebesar 94,6 $\%$. Selain itu, didapatkan persamaan regresi berdasarkan rumus $y=a+b x$ yaitu $y=72,253-0,599 x$ dengan y adalah nilai SNR, $x$ adalah tegangan tabung sinar-X, 72,253 adalah konstanta, dan $-0,599$ 
adalah koefisien regresi. Koefisien regresi bernilai negatif artinya semakin besar variasi tegangan tabung sinar-X maka nilai SNR akan semakin kecil, hal ini juga ditunjukkan oleh grafik pada Gambar 5.

Tabel 1. Hasil perhitungan nilai Signal to Noise Ratio (SNR).

\begin{tabular}{|c|c|c|c|c|c|c|c|}
\hline \multirow{2}{*}{ Step } & \multirow{2}{*}{ Ketebalan (mm) } & \multicolumn{6}{|c|}{ SNR } \\
\hline & & $40 \mathrm{kV}$ & $50 \mathrm{kV}$ & $60 \mathrm{kV}$ & $70 \mathrm{kV}$ & $80 \mathrm{kV}$ & $90 \mathrm{kV}$ \\
\hline 1 & 31,5 & 69,505 & 55,875 & 56,778 & 48,153 & 38,534 & 30,004 \\
\hline 2 & 30,0 & 72,405 & 53,611 & 52,551 & 45,485 & 35,852 & 28,176 \\
\hline 3 & 28,5 & 72,552 & 52,503 & 50,845 & 43,976 & 34,707 & 27,130 \\
\hline 4 & 27,0 & 72,658 & 51,558 & 49,669 & 42,995 & 34,011 & 26,406 \\
\hline 5 & 25,5 & 71,791 & 50,251 & 48,346 & 41,672 & 33,085 & 25,742 \\
\hline 6 & 24,0 & 70,286 & 49,082 & 46,988 & 40,097 & 31,794 & 24,734 \\
\hline 7 & 22,5 & 68,864 & 47,803 & 45,176 & 38,759 & 30,658 & 23,606 \\
\hline 8 & 21,0 & 67,030 & 46,180 & 43,033 & 37,445 & 29,581 & 22,658 \\
\hline 9 & 19,5 & 64,846 & 43,904 & 41,276 & 35,712 & 28,464 & 21,775 \\
\hline 10 & 18,0 & 61,595 & 41,650 & 39,441 & 33,481 & 26,737 & 20,544 \\
\hline 11 & 16,5 & 58,273 & 39,432 & 37,233 & 31,708 & 25,168 & 19,166 \\
\hline 12 & 15,0 & 54,413 & 37,353 & 34,692 & 30,066 & 23,964 & 18,153 \\
\hline 13 & 13,5 & 50,542 & 34,516 & 32,575 & 28,322 & 22,788 & 17,307 \\
\hline 14 & 12,0 & 45,784 & 31,747 & 30,294 & 26,208 & 21,453 & 16,355 \\
\hline 15 & 10,5 & 41,318 & 29,921 & 28,602 & 24,173 & 19,697 & 15,077 \\
\hline 16 & 9,0 & 37,001 & 27,942 & 26,105 & 22,445 & 18,356 & 13,909 \\
\hline 17 & 7,5 & 33,315 & 26,212 & 23,911 & 20,768 & 17,163 & 12,921 \\
\hline 18 & 6,0 & 29,037 & 23,716 & 21,686 & 18,488 & 15,961 & 11,805 \\
\hline 19 & 4,5 & 24,057 & 20,727 & 18,494 & 15,449 & 13,534 & 10,086 \\
\hline 20 & 3,0 & 17,888 & 17,272 & 14,729 & 11,681 & 10,900 & 7,728 \\
\hline \multirow[t]{2}{*}{21} & 1,5 & 9,844 & 11,850 & 8,147 & 6,849 & 7,002 & 4,730 \\
\hline & Rata-rata & 52,048 & 37,767 & 35,742 & 30,663 & 24,734 & 18,953 \\
\hline
\end{tabular}

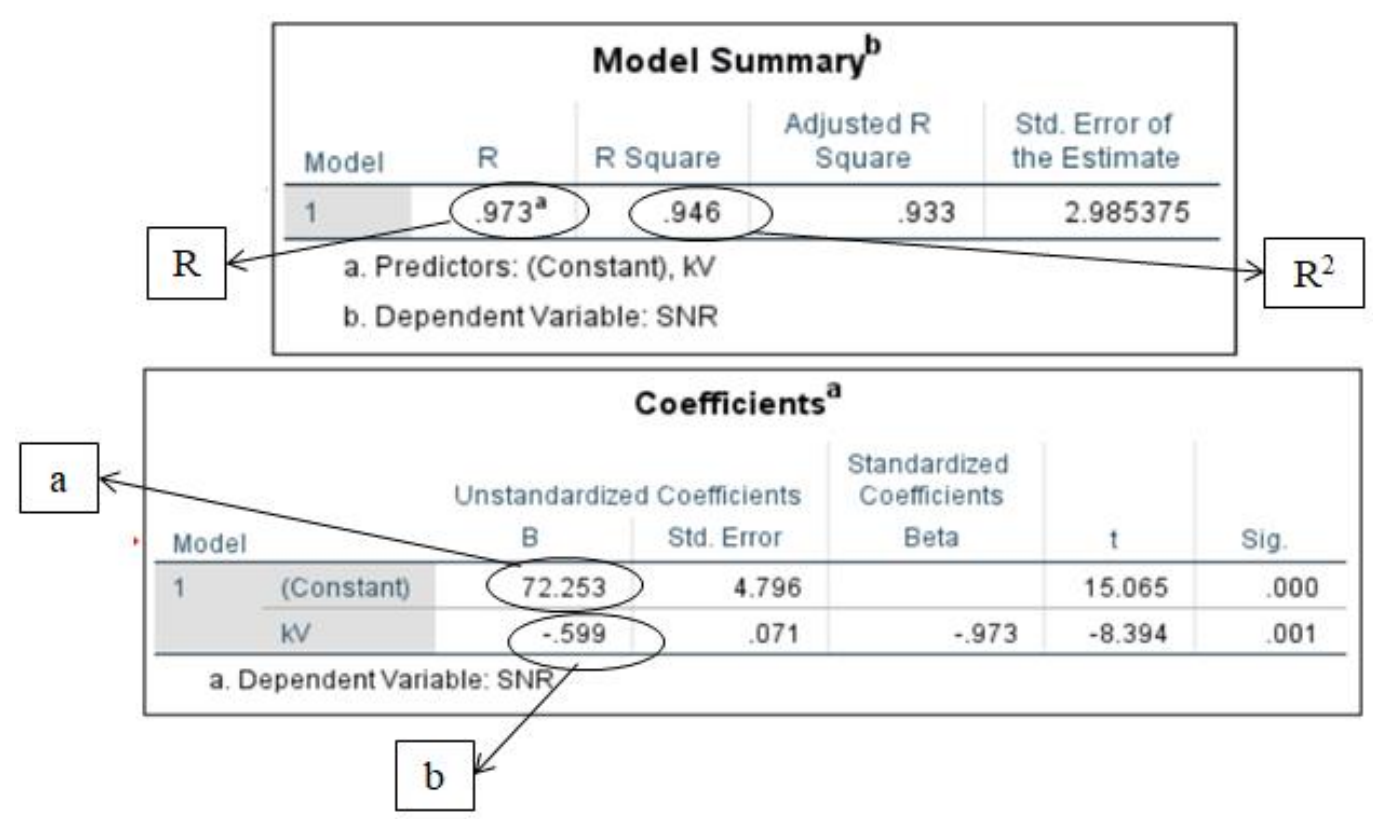

Gambar 4. Analisi pengaruh variasi tegangan tabung sinar-X dengan nilai SNR menggunakan uji regresi sederhana. 


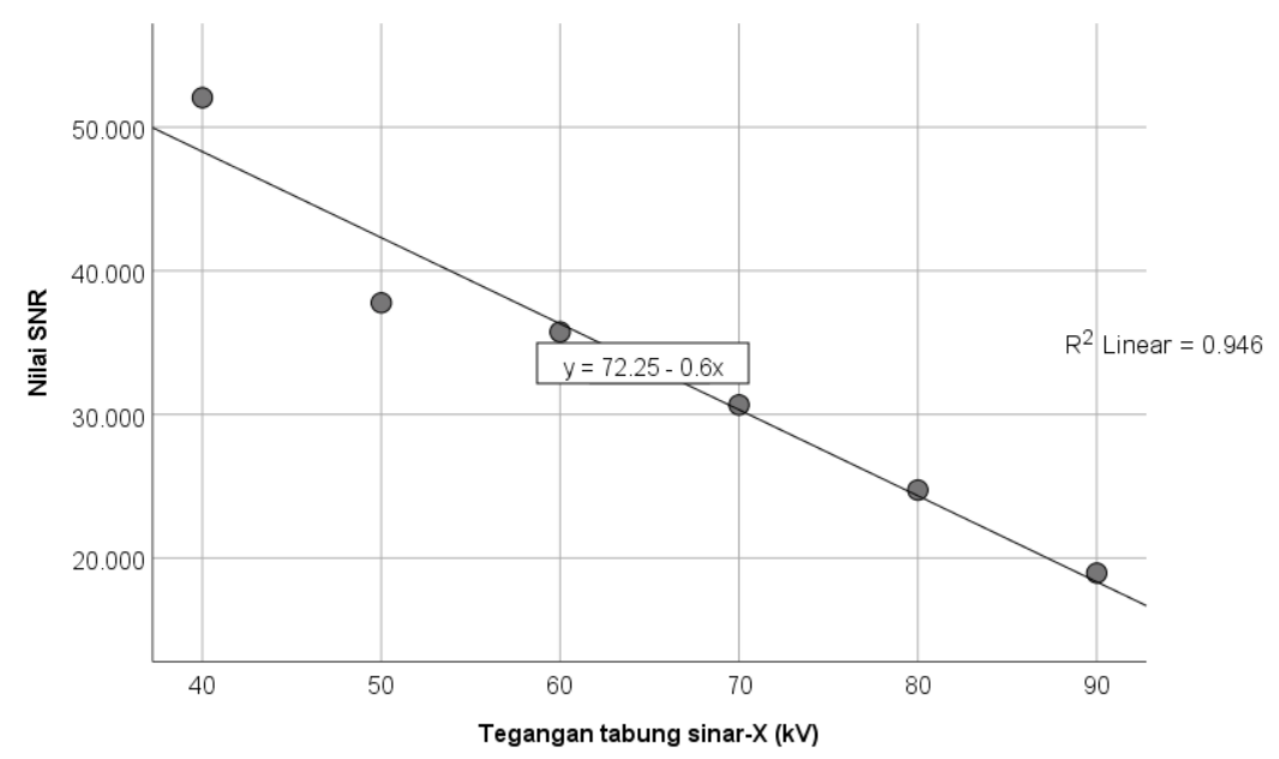

Gambar 5. Grafik variasi tegangan tabung sinar-X (x) dengan nilai SNR (y).

Selanjutnya grafik variasi ketebalan stepwedge terhadap nilai SNR pada masing-masing tegangan tabung sinar-X ditunjukkan pada Gambar 6.

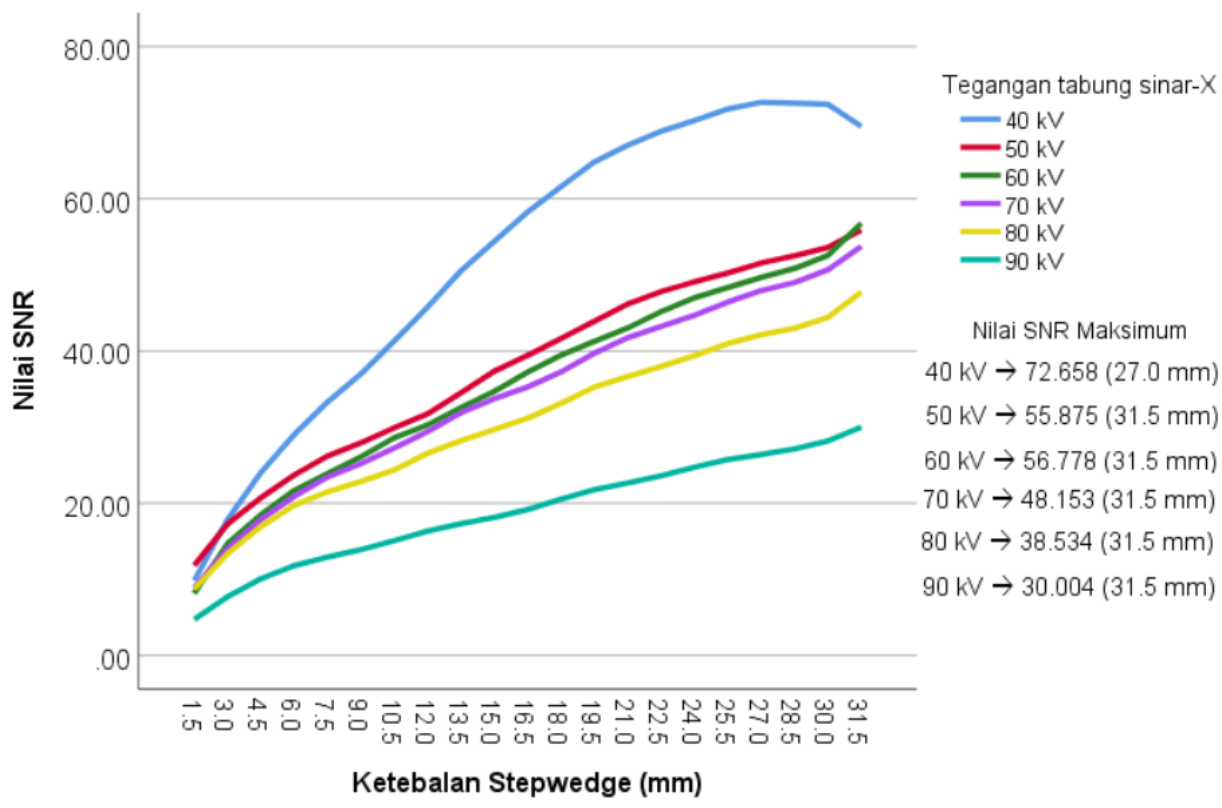

Gambar 6. Grafik hubungan antara variasi ketebalan stepwedge terhadap nilai SNR pada setiap tegangan tabung sinar-X.

Pada Gambar 6 menunjukkan secara umum bahwa semakin besar ketebalan stepwedge, maka semakin besar juga nilai SNRnya. Selain itu, ditunjukkan juga nilai SNR maksimum dari masing-masing tegangan tabung sinar-X. Nilai SNR pada tegangan tabung sinar-X $40 \mathrm{kV}$ mengalami peningkatan dari ketebalan 1,5 $\mathrm{mm}$ hingga puncaknya pada ketebalan $27,0 \mathrm{~mm}$. Namun pada ketebalan $28,5 \mathrm{~mm}$, nilai SNR mengalami penurunan. Nilai SNR pada ketebalan 27,0 mm merupakan nilai SNR yang optimal yaitu sebesar 72,658. Pada tegangan tabung sinar-X 50, 60, 70, 80, dan $90 \mathrm{kV}$, nilai SNR mengalami peningkatan dari ketebalan $1,5 \mathrm{~mm}$ sampai $31,5 \mathrm{~mm}$ dan ada kemungkinan akan terus mengalami peningkatan jika ditambahkan variasi ketebalan. Namun stepwedge yang digunakan terbatas pada ketebalan maksimum sebesar $31,5 \mathrm{~mm}$, sehingga belum didapatkan nilai SNR yang optimal pada tegangan tersebut. Hasil tersebut menunjukkan bahwa objek dengan ketebalan seperti stepwedge dapat menghasilkan citra yang optimal dengan menggunakan tegangan tabung sinar-X $40 \mathrm{kV}$. 
Variasi tegangan tabung sinar-X akan mempengaruhi hasil citra. Jika $\mathrm{kV}$ ditingkatkan, maka densitas dari citra juga akan meningkat. Semakin tinggi densitas maka citra akan semakin hitam. Citra yang berdensitas tinggi menyebabkan hasil gambaran yang didapat gelap dan objek yang digunakan tidak terlihat sehingga tidak dapat digunakan untuk mendiagnosis suatu penyakit [12]. Pada pencitraan digital, pixel dari citra akan semakin hitam jika nilainya semakin mendekati 0 . Densitas berhubungan dengan nilai SNR yang dihasilkan, dimana semakin tinggi densitasnya maka nilai $\mathrm{I}_{\mathrm{s}}$ akan semakin kecil dan diikuti dengan semakin kecil juga nilai SNRnya [4]. Hal ini juga sudah sesuai dengan hasil penelitian ini, dimana semakin besar variasi tegangan tabung sinar-X maka nilai SNR semakin kecil.

Nilai SNR menunjukkan kualitas citra digital atau kemampuan untuk memvisualisasikan organ tubuh. Nilai SNR yang meningkat artinya kekuatan sinyal lebih tinggi dibandingkan dengan jumlah noise sehingga kualitas citra juga ikut meningkat [4]. Semakin tinggi nilai SNR maka kualitas citra yang dihasilkan akan semakin baik, artinya citra dengan nilai SNR paling besar adalah citra yang optimal. Kualitas citra yang baik artinya citra dapat menunjukkan bagian organ tubuh secara akurat dan dapat digunakan untuk mendiagnosis.

Hasil penelitian ini dapat menjadi acuan dalam pemeriksaan organ tubuh dengan menggunakan sinar$X$, dimana diperlukan kewaspadaan dalam menentukan tegangan tabung sinar- $X$ yang digunakan. Tegangan tabung sinar-X merupakan faktor dominan dalam menghasilkan tingkat energi sinar-X yang digunakan untuk menembus objek [13]. Dalam menghasilkan citra dengan densitas yang sesuai untuk menggambarkan organ tubuh, diperlukan tegangan tabung sinar-X yang sesuai juga. Tegangan tabung sinar-X yang digunakan pada setiap organ tubuh berbeda-beda tergantung ketebalannya. Jika tegangan tabung sinar-X terlalu tinggi, maka densitas citra yang dihasilkan semakin tinggi dan nilai SNR akan menjadi rendah [4]. Karena hal itulah sangat penting untuk menentukan $\mathrm{kV}$ yang digunakan pada suatu penyinaran sehingga menghasilkan citra yang sesuai dan dapat digunakan untuk mendiagnosis pasien.

\section{Kesimpulan}

Berdasarkan hasil dan pembahasan, maka dapat disimpulkan bahwa variasi tegangan tabung sinar-X berpengaruh terhadap nilai SNR, dimana semakin besar variasi tegangan tabung sinar-X maka nilai SNR semakin kecil. Nilai SNR optimal yaitu 72,685 diperoleh pada tegangan tabung $40 \mathrm{kV}$ dan tebal stepwedge $27,0 \mathrm{~mm}$.

\section{Ucapan Terima Kasih}

Ucapan terimakasih ditujukan kepada seluruh staff di Akademi Teknik Radiodiagnostik dan Radioterapi (ATRO) Bali atas izin dan bantuannya sehingga penelitian ini dapat terlaksana.

\section{Pustaka}

[1] I M. Hendra, N. N. Rupiasih, Pemantauan Dosis Serap Radiasi Sinar-X pada Pemeriksaan Toraks, Buletin Fisika Journal, vol. 21, no.1, 2020, pp 8-13.

[2] Alfiati, Studi Efek Heel pada Film Radiografi [Skripsi Fisika Medik]. Makasar: Konsentrasi Fisika Medik Jurusan Fisika Medik Fakultas Matematika dan Ilmu Pengetahuan Alam Universitas Hasanuddin, 2013.

[3] S. Litasova, E. Hidayanto, M. Azam, Pengaruh Ketebalan dan Kombinasi Jenis Filter terhadap Nilai Entrance Skin Exposure (ESE) Menggunakan Faktor Eksposi Pemeriksaan Kepala, Youngster Physics Journal, vol. 07, no. 2, 2018, pp 67-75.

[4] T. L. Fauber, Radiographic Imaging and Exposure Fourth Edition, Associate Professor and Radiography Program Director, Department of Radiation Sciences, School of Allied Health Professions, Virginia Commonwealth University, Richmond, Virginia, 2012.

[5] C. Louk, dan G. B. Suparta, Pengukuran Kualitas Sistem Pencitraan Radigrafi Digital Sinar-X, Journal of Mathematics and Natural Sciences BIMIPA, vol. 24, no. 2, 2014, pp 149-166.

[6] Z. A. Afani, N. N. Rupiasih, Pengolahan Film Radiografi Secara Otomatis menggunakan Automatic X-Ray Film Processor Model JP-33, Buletin Fisika Journal, vol. 18, no. 2, 2017, pp 5357.

[7] H. Dabukke, Pengujian Iluminasi, Kolimasi, Ketegaklurusan dan Kualitas Berkas Pesawat Sinar-X Radiografi Umum dengan Radiografi Mobile [Tesis]. Medan: Program Studi Magister (S2) Fisika Fakultas Matematika dan Ilmu Pengetahuan Alam Universitas Sumatra Utara, 2018. 
[8] M. Ferryadi, Penentuan Ketepatan Titik Pusat Berkas Sinar dari Sudut Berkas Pada Pesawat General X-Ray Sebagai Parameter Kualitas Kontrol [Skripsi]. Medan: Departemen Fisika Fakultas Matematika dan Ilmu Pengetahuan Alam Universitas Sumatra Utara, 2017.

[9] R. Aryawijayanti, Analitisi Dampak Radiasi Sinar-X pada Mencit Melalui Pemetaan Dosis Radiasi di Laboratorium Fisika Medik [Skripsi]. Semarang: Jurusan Fisika Fakultas Matematika dan Ilmu Pengetahuan Alam Universitas Negeri Semarang, 2015.

[10] R. Bourne, Fundamentals of Digital Imaging in Medicine, Springer London Dordrecht Heidelberg, New York, 2009.

[11] A. Sudin, Z. Muhlisin, H. Widiyandari, Studi Pengaruh Ukuran Pixel Imaging Plate Terhadap Kualitas Citra Radiograf, Jurnal Berkala Fisika, vol. 18, no. 3, 2015, pp 89-94.

[12] F. Anita, D. A. Tunggadewi, Uji Banding Citra Film terhadap Computed Radiography (CR), Jurnal Ilmiah GIGA, vol. 23, no. 1, 2020, pp 20-26.

[13] E. Sparzinanda, Nehru, Nurhidayah, Pengaruh Faktor Eksposi terhadap Kualitas Citra Radiografi, Journal Online of Physics, vol. 3, no. 1, 2017, pp 14-22. 